\title{
Willingness of Chinese, Studying in Germany to Fly Back to China Due to Their Risk Perception About COVID-19
}

\author{
Xuguang Zhu (D) ' \\ Muhammad Ishfaq Ahmad (iD) ${ }^{2}$ \\ Ramiz Ur Rehman ${ }^{2}$ \\ Muhammad Akram Naseem ${ }^{2}$ \\ Muneeb Ahmad 1,3 \\ 'College of Innovation and Practice, \\ Liaoning Technical University, Fuxin, \\ Liaoning, People's Republic of China; \\ ${ }^{2}$ Lahore Business School, The University \\ of Lahore, Lahore, Punjab, Pakistan; \\ ${ }^{3}$ School of Education and Management, \\ Anshan Normal University, Anshan, \\ Liaoning, People's Republic of China
}

Correspondence: Muhammad Ishfaq Ahmad I-KM Raiwind Raod, Lahore, Punjab, Pakistan

Tel +92-333-4622693

Email m_ishfaq452@yahoo.com
Purpose: In this study, we aimed to examine the risk perception of Chinese students studying in Germany, which is the country fifth-most affected by COVID-19 in the world, who wish to return to China.

Patients and Methods: After controlling the COVID-19 situation in the country, China reopened the entire country, including Wuhan, which was the epicenter of the COVID-19 pandemic. A well-structured questionnaire was sent to Chinese students through a WeChat survey, a special feature within this mobile application, similar to Google Docs. The link was sent to 2000 students studying in Germany, and we received 1232 responses.

Results: The study found that the majority of Chinese students are willing to come back to China, considering the current risk of COVID-19 in Germany. A higher mortality rate influences their wish to return to China. Additionally, the special family size of "One Child" in the family also a key driver of Chinese student's wish to get back home.

Conclusion: This study provides useful information to policymakers to implement proactive measures to manage students who want to return to China, as they may be the cause of the second wave of COVID-19 in China.

Keywords: one child, risk perception, higher mortality rate

\section{Introduction}

The whole world is currently fighting with the deadly coronavirus disease, and people are desperately searching for places "where there is no coronavirus." However, among the 200 countries and territories in the world, 181 have reported confirmed cases of the disease. ${ }^{1}$ The COVID-19 pandemic originated from Wuhan city, China, in late December 2019 and has now spread globally. Initially, it affected China gravely, while also slowly emerging in the rest of the world. At the time, there were discussions about the Chinese economy ${ }^{2}$ and the future of big players in China, comparing the report of SARS Medical News Today, and various countries decided to bring back their citizens from China. ${ }^{3}$ Within days and months, the disease spread across the globe via international and local transmission. Initially, cases emerged through international transmission, ${ }^{4}$ but later, the spread of COVID-19 through local transmission was reported. ${ }^{5-7}$ In this way, the effect of the disease on mature economies like the USA was far worse than even that on China. Italy, Spain, and Germany are among the worstaffected economies and are ranked higher than even China in this regard. ${ }^{8}$ 
However, many countries took strong actions on the mobility of individuals and stopped flight operations starting from the USA, UK, and China. ${ }^{9}$ Countries that implemented the lockdown and followed the guidelines properly are in a better condition as compared to those that did not take these guidelines seriously. As COVID-19 is transmitted from one individual to another, the concept of a global village plays a significant role in the transmission. People continued to travel even as they were advised to restrict travel, and this has led to the serious situation today. During the outbreak in China, many countries brought their students back to their homes through chartered flights (USA and UK), while many refused to do so such as Pakistan ${ }^{10}$ and Nepal ("China defends," 2020). ${ }^{11}$

Undoubtedly, China undertook exemplary measures to fight against COVID-19 by implementing a countrywide lockdown without caring about the economic losses and built hospitals within days to save the lives of the people. China took extreme care of foreign citizens as well and won the trust of many countries like Pakistan. Compared to the rest of the world, China seems to have controlled the COVID-19 better, and thus, the country could reopen by April 8, 2020. ${ }^{12}$ As of now, China is considered to be the safest place on earth as compared to the rest of the world, where people are still suffering from the rapid spread of COVID-19. In this crucial time, everyone wants to move to the safe place, especially the Chinese students who are studying in the Europe and US, the most affected regions by the COVID-19. In response to this serious issue, scientists have made advances in characterizing the novel coronavirus within months and worked on vaccines to combat it. While the scientific community focused on health issues to defeat this virus, others contributed in the literature on other issues such as cases (deaths) of COVID to both meteorological (eg, temperature and relative humidity) and air quality variables. ${ }^{13-15}$ In contrast, the role of human mobility on the spread of the COVID-19 was not still deeply investigated.

This study fills this gap by addressing an important issue, of people mobility from an affected region to the comparably less affected or controlled region, and that may cause the spread of COVID-19 again in these regions. The study examines the willingness of Chinese students to return to China during the outbreak in Germany based on their risk perception. This study contributes to the existing literature of people mobility and COVID-19 spread, especially in the student context due to the large body of international students around the world. Second, this study contributes to how different variables such as knowledge and safety can reduce the people mobility from one place to another place. We expect that more than one reason motivates Chinese students to go back to their home town, such as one kid in the family and severity of disease with high mortality rate in the country. This is a challenging situation not only for the students but also for the Chinese government to host the students returning from affected countries since it might cause a second wave of COVID-19 infection in China. Therefore, the results of this study might facilitate the policymakers to take proactive measures to host the returning students to protect the country from a possible second wave of COVID-19. Germany hosts a reasonable number of Chinese students, who account for $13 \%$ of the total number of international students in Germany. Germany is also the fourth-largest host country of international students worldwide after the United States, the United Kingdom, and Australia.

\section{Patients and Methods}

Our target population was the Chinese students studying in Germany. A well-structured questionnaire was used to ask Chinese students about their willingness to return to China based on their perception of the risk of COVID-19. The measurement of risk perception is quite complex due to subjectivity, and it is hard to measure it quantitatively. Therefore, in this study, we measured the risk in two aspects of the magnitude of risk, which is based on the probability measure of the spread and mortality rate of epidemic outbreak in the region within a month. First, the magnitude of risk was measured by asking one question: whether the magnitude of the said outbreak is high or low based on the probability calculation of its spread and mortality rate. Second, the risk perception was measured through the psychometric framework developed by Paul Slovic (1987). ${ }^{16}$ This psychometric framework is extensively used in the literature ${ }^{17,18}$ and was even used during the SARS outbreak Liu et al. ${ }^{19}$ Out of the seven risk measures, the study considered severity, danger, knowledge, personal control, concern, and safety for the outbreak of this disease. Every type of risk was measured through a single question, and a sample question is as follows:

"Do you think COVID-19 emerged severely in Germany?" "Not at all, 1, 2, 3, 4, 5, Severe". 
Table I Sample Profile

\begin{tabular}{|l|c|c|c|}
\hline S. No. & $\begin{array}{c}\text { Provincel } \\
\text { City }\end{array}$ & Number of Students & Sample in \% \\
\hline 1 & Munich & 396 & $32.14 \%$ \\
2 & Berlin & 362 & $28.39 \%$ \\
3 & Stuttgart & 243 & $19.72 \%$ \\
4 & Hamburg & 155 & $12.58 \%$ \\
5 & AaChen & 76 & $6.17 \%$ \\
\hline Total & Total & 1232 & $100 \%$ \\
\hline
\end{tabular}

The willingness of students to return to China was determined through a dichotomous question with an option of Yes or No. The survey also contained questions about the demographics and socioeconomic situation after the COVID-19 outbreak. The data was collected through the WeChat survey, like Google Doc. The survey was conducted from March 15 till June 30, 2020. The study used a non-probabilistic sampling technique. The link was sent to 2000 students studying in Germany by sending our link in the WeChat groups of Chinese students in Germany, and we received 1232 responses. These WeChat groups are created by German Chinese students' community to help each others. The survey was set up in a way that the potential participant after the consent form chooses his/her nationality. If the respondent is a Chinese national, it moves to the next steps, otherwise exit automatically. Table 1 shows the profile of the respondents.

The respondents resided in five cities of Germany, and the majority of the respondents resided in the worstaffected cities of Germany, such as Berlin and Munich (Statista) with $28.39 \%$ and $32.14 \%$ respondents, respectively. The participation of Chinese students from different cities of Germany helped us to measure the risk perception of Chinese students across the country and simultaneously push the policymakers to make more sound policies for them, as they want to return to China from the most affected cities of Germany. Variables' description is provided in Table 2.

The risk was measured through dummy as a dummy variable, and Table 2 shows that the magnitude of risk among students is high and ultimately influences their decision to return to their home countries. The majority of the students are wearing the mask, which shows that they are taking preventive measures to save themselves from the coronavirus. The mortality rate is perceived as high due to the increasing death rate. ${ }^{7,20}$ Most of the students are young, enrolled in the undergraduate or master's degree programs and are unmarried. Table 3 shows the categorical variables.

The abovementioned categorical variables are measured through the five-point Likert scale. Chinese students in Germany believe that COVID-19 will not only

Table 2 Summary Statistics and Variables Description of Dummy Variables

\begin{tabular}{|c|c|c|c|c|}
\hline Variables & Nature & Description & Yes & No \\
\hline Risk & Dummy & $I$ if risk per month $=3 * 10^{-10}, 0$ if $3 * 10^{-2}$ & $90 \%$ & $10 \%$ \\
\hline Mortality risk & Dummy & I if conditional morality risk is $0.20,0$ if 0.10 & $68 \%$ & $32 \%$ \\
\hline Sex & Dummy & I if male, 0 if female & $55 \%$ & $45 \%$ \\
\hline Marital status & Dummy & I if married, 0 if otherwise & $23 \%$ & $77 \%$ \\
\hline Religious belief & Dummy & I if the respondent has any religion, 0 if otherwise & $13 \%$ & $87 \%$ \\
\hline Mask & Dummy & I if the respondent wears mask outside, 0 if otherwise & $93 \%$ & $7 \%$ \\
\hline Flu shot & Dummy & I if the respondent had flu in 6 months, 0 if otherwise & $12 \%$ & $88 \%$ \\
\hline Willingness to return & Dummy & I if respondent is willing to return to home country, 0 if otherwise & $68 \%$ & $32 \%$ \\
\hline \multirow[t]{4}{*}{ Education } & \multirow[t]{4}{*}{ Categorical } & Graduation & $22 \%$ & $88 \%$ \\
\hline & & Master & $57 \%$ & $43 \%$ \\
\hline & & $\mathrm{PhD}$ & $18 \%$ & $82 \%$ \\
\hline & & Post Doc & $3 \%$ & $97 \%$ \\
\hline
\end{tabular}


Table 3 Summary Statistics and Variables Description of Categorical Variables

\begin{tabular}{|c|c|c|c|c|c|c|}
\hline Variables & Nature & Description & Min & Max & Mean & Std \\
\hline Age & In years & Students age in years & 21 & 35 & 23 & $\mathrm{I} .14$ \\
\hline Family size & $\begin{array}{l}\text { No. of } \\
\text { persons in } \\
\text { a family }\end{array}$ & Family members & I & 3 & 2 & 1.04 \\
\hline $\begin{array}{l}\text { Health } \\
\text { status }\end{array}$ & Categorical & $\begin{array}{l}\text { Perceived health status ranges from extremely poor to excellent on a five-point } \\
\text { Likert scale }\end{array}$ & I & 5 & 4.12 & 1.08 \\
\hline Economy & Categorical & $\begin{array}{l}\text { Respondents' perception about COVID-19 serious impact on German's economy } \\
\text { ranges from not at all to extremely serious on a five-point Likert scale }\end{array}$ & 1 & 5 & 4.59 & 0.52 \\
\hline Study & Categorical & $\begin{array}{l}\text { Perception that COVID-19 will influence their studies ranges from not at all to } \\
\text { serious. Influence measured through a five-point Likert scale. }\end{array}$ & 1 & 5 & 4.32 & 1.12 \\
\hline Severity & Categorical & $\begin{array}{l}\text { Severity of COVID-19 in Germany ranges from not at all serious to extremely } \\
\text { serious Measured through a five-point Likert scale }\end{array}$ & I & 5 & 4.76 & 1.32 \\
\hline Danger & Categorical & $\begin{array}{l}\text { Effects of COVID-19 risk on respondent's life range from not at all to extremely } \\
\text { serious Measured through a five-point Likert scale }\end{array}$ & I & 5 & 4.50 & 1.85 \\
\hline Knowledge & Categorical & $\begin{array}{l}\text { Knowledge on how COVID-19 spread from little knowledge to much knowledge } \\
\text { measured through a five-point Likert scale }\end{array}$ & I & 5 & 4.12 & 0.96 \\
\hline $\begin{array}{l}\text { Personal } \\
\text { control }\end{array}$ & Categorical & $\begin{array}{l}\text { Degree of personal control of COVID-19 risk ranges from not at all to extremely } \\
\text { controllable Measured through a five-point Likert scale }\end{array}$ & I & 5 & 4.22 & 1.65 \\
\hline Concern & Categorical & $\begin{array}{l}\text { Concern about COVID-I } 9 \text { infection ranges from not at all to extremely concerned } \\
\text { Measured through a five-point Likert scale }\end{array}$ & I & 5 & 4.52 & 1.32 \\
\hline Safety & Categorical & $\begin{array}{l}\text { Perception of safety in Germany ranges from not at all to fully safe Measured } \\
\text { through a five-point Likert scale }\end{array}$ & I & 5 & 3.32 & 0.83 \\
\hline
\end{tabular}

affect the German economy severely but will also influence their studies. The Chinese students showed high concern about the COVID-19 as death grim records ${ }^{8,21}$ however demonstrated that they have enough knowledge $^{22}$ about it and believe that it is under personal control. This result shows that local governments promote the knowledge of social distancing and washing hands that will increase the people perception that it can be under control. This confidence leads to people less mobility during this pandemic. It may be true as they are getting safety advice from their parents. Although they rated themselves healthy enough with a 4.59 value on an average with the standard deviation of 1.08 , they showed higher concern regarding the severity of the situation at 4.76 (SD 1.32) that influences their willingness to return to China. Although the German government took strong measures and made tests available around the country, it could not achieve enough confidence of Chinese students as evident by the value of 3.32 (SD 0.83) regarding safety.

\section{Results and Discussion}

In Table 4, we have summarized the results of three maximum likelihood methods. Using the first model, we examined the influence of demographics on the willingness of students to return to their home countries. Using the second model, we examined the role of the risk perception variable on the willingness of students to return. In the last model, the magnitude of risk variables contributing to the students' willingness to return to China was assessed. Age and family size and education significantly increased the willingness of students to return to China. As expected, family size appears to matter to a large extent because Chinese parents with one child are highly concerned about their child, as indicated in the study conducted by Yang (2004). ${ }^{23}$ Moreover, it has been 
Table 4 Regression Analysis

\begin{tabular}{|c|c|c|c|c|c|c|c|c|c|c|c|c|}
\hline \multirow[t]{2}{*}{ Variables } & \multicolumn{4}{|c|}{ I } & \multicolumn{4}{|c|}{2} & \multicolumn{4}{|c|}{3} \\
\hline & B & SE & Wald & OR & B & SE & Wald & OR & B & SE & Wald & OR \\
\hline Constant & 8.52 & 2.32 & 45.12 & 0.00 & 2.22 & 2.12 & 9.42 & 0.02 & -3.62 & 1.42 & 3.72 & 0.19 \\
\hline Sex & $0.97^{* * *}$ & 0.04 & 5.83 & 1.32 & & & & & & & & \\
\hline Marital status & 0.18 & 0.08 & 0.53 & 1.32 & & & & & & & & \\
\hline Age & $0.09 * *$ & 0.03 & 8.53 & 1.03 & & & & & & & & \\
\hline Family size & $0.09 * * *$ & 0.06 & 9.12 & 1.02 & & & & & & & & \\
\hline Education & 0.07 & 0.05 & 0.83 & 1.02 & & & & & & & & \\
\hline Health status & & & & & 0.03 & 0.04 & 0.92 & 1.08 & & & & \\
\hline Study & & & & & 0.22 & 0.03 & 0.96 & 0.64 & & & & \\
\hline Severity & & & & & $0.08^{* * *}$ & 0.02 & 6.65 & 1.08 & & & & \\
\hline Danger & & & & & $0.96 *$ & 0.22 & 3.29 & 1.03 & & & & \\
\hline Knowledge & & & & & 0.05 & 0.08 & 0.12 & 1.02 & & & & \\
\hline Personal control & & & & & $-0.26 *$ & 0.12 & 5.37 & 0.89 & & & & \\
\hline Concern & & & & & $0.54 * *$ & 0.18 & 3.25 & 1.32 & & & & \\
\hline Safety & & & & & $-0.80^{*}$ & 0.09 & 12.56 & 2.06 & & & & \\
\hline Mortality & & & & & & & & & $-0.52 * * *$ & 0.18 & 9.32 & 1.42 \\
\hline Risk & & & & & & & & & $-0.21 * * *$ & 0.13 & 7.52 & I.7I \\
\hline Religion & & & & & & & & & 0.12 & 0.12 & 0.67 & 1.26 \\
\hline Flu shot & & & & & & & & & 1.1 & 1.07 & 0.09 & 4.00 \\
\hline \multicolumn{2}{|l|}{ City } & \multicolumn{3}{|l|}{ Yes } & \multicolumn{4}{|l|}{ Yes } & \multicolumn{4}{|l|}{ Yes } \\
\hline \multicolumn{2}{|l|}{ Model significance } & \multicolumn{3}{|c|}{$53.43(0.00)^{* * *}$} & \multicolumn{4}{|c|}{$42.18(0.00)^{* * * * *}$} & \multicolumn{4}{|c|}{$73.62(0.00) * * *$} \\
\hline \multicolumn{13}{|l|}{ Model summary } \\
\hline \multicolumn{2}{|l|}{-2 log likelihood } & \multicolumn{3}{|c|}{114.32} & \multicolumn{4}{|l|}{289.45} & \multicolumn{4}{|l|}{389.45} \\
\hline \multicolumn{2}{|l|}{ Cox and Snell R2 } & \multicolumn{3}{|l|}{0.06} & \multicolumn{4}{|l|}{0.18} & \multicolumn{4}{|l|}{0.13} \\
\hline \multicolumn{2}{|l|}{ Nagelkerke R2 } & \multicolumn{3}{|l|}{0.05} & \multicolumn{4}{|l|}{0.14} & \multicolumn{4}{|l|}{0.18} \\
\hline
\end{tabular}

Notes: $* * * 1 \%$, $* 5 \%$ and $* 10 \%$ level of significance.

reported that gender contributes significantly, and Chinese families with one child also have a preference towards a boy ${ }^{24}$ and that is one reason that gender contributes significantly to their willingness to return to China.

In the second model, we examined how the perception of risk of COVID-19 has driven the willingness of Chinese students to return to China. The model showed that due to the current situation in Germany, students are least concerned about their studies, and thus, this aspect remained insignificant. The current situation in Germany is identified as the key driver for the students' willingness to return to China, which is evident $\left(0.08^{* * *}\right.$ significant at $1 \%$ level of confidence). Moreover, the danger and severity have also been identified to contribute positively to their willingness to return to China. The results confirm the study of Indian domestic and international travelers' intention to fly during COVID-19. ${ }^{25}$ This shows that severity of COVID-19 itself is the key driver of people mobility and that is the reason 
Chinese students are willing to return back from Germany. Interestingly, the perception about COVID-19 and personal control has a significant negative relationship with their willingness to return to China. Therefore, these findings indicate that if any country is successful in communicating to its citizens that the key to combat coronavirus disease is personal control, it can win the trust of its citizens stranded abroad. The safety measures against COVID-19 showed a negative relationship with the students' willingness to return to China, but the result is significant at $10 \%$ level of confidence.

The last model as presented in column three examined the magnitude of risk and willingness of Chinese students to return to China. This model showed that a low mortality rate would lead to less willingness of students to return to China. Moreover, the risk of spread is also negatively related to the students' willingness to return to China. Countries that responded to the pandemic in a timely manner did not only control the mortality rate, but also the people in that area are less willing to move in the case of Chinese students studying in Germany. Overall, this model is significant, and we have added the models of cities as the majority of the respondents are from cities that are severely affected.

\section{Conclusion}

In this study, we aimed to assess the risk associated with Chinese students studying in Germany and their willingness to return to China. Undoubtedly, China is safer than the rest of the world, as the Chinese government did a great job with overcoming the COVID-19 situation in the country. Many analysts have predicted the second wave of COVDI-19 in China, and students returning from highly affected countries like Germany might act as the potential source of the second wave, as indicated in this study by assessing their willingness to return to China. Therefore, this article could facilitate the Chinese government to take proactive measures to manage these Chinese students who wish to return to China, once they get an opportunity to do so. The results showed that the risk of COVID-19 is severe and has spread threat among the students, which may be the reason for their willingness to return to China. Moreover, the risk can be reduced and controlled by an individual's actions and by taking more safety measures. The results of this study could also help other countries like India, which contributes to the 2nd biggest inflow of international students in Germany, in planning serious precautionary measures before bringing back their citizens studying in Germany.

\section{Ethics Approval and Consent to Participate}

The study was approved by the ethics committee of the Anshan Normal University (Ref.No.2021 ANURP701). This study was conducted in accordance with the ethical standards laid down in the 1964 Declaration of Helsinki and its later amendments. All the participants provided written, informed consent to participate in the study after receiving a description of the aims. The survey was set up in a way that the potential participant first read the consent/assent information and then clicked on a "button" in a response indicating that he/she/they have read the consent/assent information and agreed to participate. If they select Agree to participate, they move to the next steps, otherwise exit automatically. Confidentiality and anonymity were ensured. Instructions were mentioned clearly. Participants were given the right to withdraw from the study at any time, and their responses would not be included in the study.

\section{Acknowledgments}

We are very thankful to Prof. Dr. Wang for his valuable comments and guidance throughout this project.

\section{Author Contributions}

All authors made substantial contributions to conception and design, acquisition of data, or analysis and interpretation of data; took part in drafting the article or revising it critically for important intellectual content; gave final approval of the version to be published; have agreed on the journal to which the article has been submitted; and agree to be accountable for all aspects of the work.

\section{Disclosure}

The authors report no conflicts of interest in this work.

\section{References}

1. Where in the world are there no coronavirus cases? The Diplomate. Available from: https://thediplomat.com/2020/04/where-in-the-worldare-there-no-coronavirus-cases/. Accessed August 2, 2020.

2. With its epidemic slowing, China tries to get back to work. The Economist. Available from: https://www.economist.com/finance-andeconomics/2020/02/27/with-its-epidemic-slowing-china-tries-to-getback-to-work. Accessed August 2, 2020. 
3. Factbox: countries evacuating nationals from China coronavirus areas. Routers. Available from: https://www.reuters.com/article/uschina-health-evacuation/factbox-countries-evacuating-nationals-from -china-coronavirus-areas-idUSKBN2040HU. Accessed August 15, 2020.

4. Khurshid Z, Asiri FYI, Al Wadaani H. Human saliva: non-invasive fluid for detecting novel coronavirus (2019-nCoV). Int J Environ Res Public Health. 2020;17(7):2225. doi:10.3390/ijerph17072225

5. Zu J, Li M-L, Li Z-F, et al. Transmission patterns of COVID-19 in the mainland of China and the efficacy of different control strategies: a data- and model-driven study. Infect Dis Poverty. 2020;9(1):1-14. doi:10.1186/s40249-020-00709-z

6. Badr HS, Du H, Marshall M, et al. Association between mobility patterns and COVID-19 transmission in the USA: a mathematical modelling study. Lancet Infect Dis. 2020;20(11):1247-1254. doi:10.1016/S1473-3099(20)30553-3

7. He J, Chen G, Jiang Y, et al. Comparative infection modeling and control of COVID-19 transmission patterns in China, South Korea, Italy and Iran. Sci Total Environ. 2020;747(141447):1-15. doi:10.1016/j.scitotenv.2020.141447

8. Pillai S, Siddika N, Apu EH, et al. COVID-19: situation of European countries so far. Arch Med Res. 2020;51(7):723-725. doi:10.1016/j. arcmed.2020.05.015

9. China grows isolated as airlines cancel more than 50,000 flights amid coronavirus epidemic. CNBC. Available from: https:/www.cnbc. com/2020/02/06/coronavirus-china-becomes-increasingly-isolated-as -airlines-pull-out.html. Accessed September 3.

10. Abi-Habib M. As foreigners flee China, Pakistan tells its citizens to stay. The New York Times. February 11, 2020. Available from: https://www.nytimes.com/2020/02/11/world/asia/chinaoronaviruspakistan.html. Accessed September 15, 2020.

11. China defends Pak, Nepal's decision to not to evacuate their nationals from virus-hit Wuhan. Times of India. February 11, 2020. Available from: https://timesofindia.indiatimes.com/world/china/china-defendspak-nepals-decision-to-not-to-evacuate-their-nationals-from-virus-hit -wuhan/articleshow/74083433.cms. Accessed September 18, 2020.

12. Wuhan has reopened after a brutal coronavirus lockdown. But Is China Ready? Time. Available from: https://time.com/5817251/ wuhan-coronavirus-lockdown-reopens/. Accessed September 18, 2020 .
13. Tosepu R, Gunawan J, Effendy DS, et al. Correlation between weather and Covid-19 pandemic in Jakarta, Indonesia. Sci Total Environ. 2020;725:138436. doi:10.1016/j.scitotenv.2020.138436

14. Xie J, Zhu Y. Association between ambient temperature and COVID-19 infection in 122 cities from China. Sci Total Environ. 2020;724:13821. doi:10.1016/j.scitotenv.2020.138201

15. Pluchino A, Inturri G, Rapisarda A, et al. A novel methodology for epidemic risk assessment: the case of COVID-19 outbreak in Italy. arXiv Preprint arXiv. 2020;2004:02739, 12.

16. Slovic P. Perception of risk. Science. 1987;236(4799):280-285. doi:10.1126/science. 3563507

17. Dobbie MF, Brown RR. A framework for understanding risk perception, explored from the perspective of the water practitioner. Risk Anal. 2014;34(2):294-308. doi:10.1111/risa.12100

18. Bouder F, Slavin D, Löfstedt R. The Tolerability of Risk: A New Framework for Risk Management. Earthscan; 2007.

19. Liu JT, Hammitt JK, Wang JD, et al. Valuation of the risk of SARS in Taiwan. Health Econ. 2005;14(1):83-91. doi:10.1002/hec.911

20. Fact check: how deadly is the coronavirus in Germany? D.W. Available from: https://www.dw.com/en/fact-check-how-deadly-isthe-coronavirus-in-germany/a-55733525. Accessed October 26, 2020.

21. Why is Germany's coronavirus death rate so low? Time. Available from: https://ime.com/5812555/germany-coronavirus-deaths/. Accessed September 18, 2020.

22. Imran E, Khurshid Z, Adanir N, et al. Dental practitioners' knowledge, attitude and practices for mouthwash use amidst the COVID-19 pandemic. Risk Manag Healthc Policy. 2021;14::605-618. doi:10.2147/RMHP.S287547

23. Yang W Perceptions of high socio-economic Chinese-American parents about their children's academic achievement, home environment, and Chinese language proficiency. 2004. (Doctoral dissertation, University of Connecticut).

24. Arnold F, Zhaoxiang L. Sex preference, fertility, and family planning in China. In: The Pop of Modern Cn. 1992:491-523.

25. Das SS, Tiwari AK. Understanding international and domestic travel intention of Indian travellers during COVID-19 using a Bayesian approach. Tour Recreat Res. 2020:1-17.
Risk Management and Healthcare Policy

\section{Publish your work in this journal}

Risk Management and Healthcare Policy is an international, peerreviewed, open access journal focusing on all aspects of public health, policy, and preventative measures to promote good health and improve morbidity and mortality in the population. The journal welcomes submitted papers covering original research, basic science, clinical \& epidemiological studies, reviews and evaluations, guidelines, expert opinion and commentary, case reports and extended reports. The manuscript management system is completely online and includes a very quick and fair peer-review system, which is all easy to use. Visit http://www.dovepress.com/testimonials.php to read real quotes from published authors. 